\title{
Tourism Information System as a Promotion Container of Tourism Business in North Sulawesi Province
}

\author{
Yonatan Parassa \\ Manado State Polytechnic
}

\author{
Mex U. Pesik \\ Manado State Polytechnic
}

\author{
Toban T. Pairunan \\ Manado State Polytechnic
}

\author{
Alma K. Pongtuluran \\ Manado State Polytechnic
}

\begin{abstract}
The growth of North Sulawesi Pariwista reached the highest growth rate in the last four years, and was awarded The Rising Destination Of The Year 2019 from the ministry of tourism. The community as business actors is expected to improve the welfare of the tourism sector. One of the ways to improve the welfare of the tourism business can be done by promoting through digital platforms, considering that now is the era of industry 4.0 .
\end{abstract}

This study aims to design a tourism information system as a promotional platform for tourism businesses in North Sulawesi Province

The design of a tourism information system as a promotional platform for business actors in North Sulawesi province is carried out using the enterprise architecture planning method

The result of this research is the design of a tourism information system as a promotion containers of tourism business in north sulawesi province, built with due observance to the needs of tourism businesses that require promotional facilities via the internet so that they can be accessed by tourists and are expected to increase the income of tourism business actors in North Sulawesi Province.

\section{Keywords}

Tourism Information System, Promotion Containers, Tourism Business, North Sulawesi Province

\section{INTRODUCTION}

Various methods have been used by the Central Government and Regional Governments to achieve the goals of the Unitary Republic of Indonesia, one of which is the welfare of the people. Increasing the welfare of the community is carried out through various programs including through the tourism sector [1].

The people and government of North Sulawesi welcomed the central government's tourism development program by taking various steps to advance the tourism sector in the province of North Sulawesi. In 2019 North Sulawesi received the rising star award, because it succeeded in boosting tourism growth by 600 percent in four years.

North Sulawesi is one of the provinces in Indonesia that has experienced very significant tourism growth and won the rising star award in 2019 because it succeeded in boosting tourism growth by 600 percent in four years [2].

In 2019 the government set five super priority destinations and one of them is Likupang, which is located in North Sulawesi [3].

Tourism is one of the largest sectors affecting economic growth [4] Given that the tourism sector is in direct contact with the community.
Now is the industrial era 4.0. On the other hand, the central government has launched a digital tourism promotion. Unfortunately, the promotion of tourism on a provincial scale in North Sulawesi through the internet has not been carried out optimally, including the promotion of tourism businesses.

The tourism business needs a digital promotional tool in the form of a website to increase sales which has implications for increasing income and boosting the welfare of the community.

This study designed a tourism information system as a promotion containers of tourism businesses in North Sulawesi province.

The result of this research is that the design of a tourism information system as promotion containers of tourism businesses in North Sulawesi province is made using the Zachman method which promotes tourism businesses on a provincial scale in North Sulawesi. With the existence of internet-based promotions regarding tourism businesses, tourists can get information to make tourist visits, so that it is hoped that it can increase tourism business income in North Sulawesi Province.

\section{LITERATUR REVIEW}

Tourism is inherently a complex system, which is a combination of elements (or subsystems) that together form a complex whole [5].

Tourists and potential tourists really need tourism information [6] including information about tourism businesses such as hotels, restaurants, culinary delights, souvenirs, tour guides and other tourism businesses.

Information about tourism businesses such as galleries, restaurants, theaters, museums, local stores, is a necessity for tourists so that they can experience the natural tourist experience of tourist destinations [7].

Tourism businesses are widely recognized as having played a role in providing experiences for tourists [8].

The tourism business by digitizing via the internet is considered more flexible and in accordance with reality [9] including promoting tourism business.

Websites are part of the internet. Various websites exist on the internet with various functions, including to disseminate information. Among them are tourism websites.

The web is considered suitable for marketing tourism because it can present information visually [10]

One of the functions of a tourism website is to direct the attention of online visitors to tourist attractions and valueadded resources, such as restaurants and hotels [11].

The quality of software is largely determined by the system design stage. [12]. 
This research uses a proven Enterprise Architecture Planning EAP as a stable framework as a method for designing systems.

The Zachman framework is used to align organizational architecture and information technology [13].

Previous studies that used EAP system design include research that examines the promotion of tourism businesses [9], [10], [14], [15], [16].

\section{RESEARCH METHOD}

Research methods reflect the approach to tackling the research problem [17].

The use of several methods to solve problems in research. This research has several methods. Architectural design of the system using the Zachman framework. Collecting data using interviews, observation and literature research.
Organizing and enterprise representations are classified in the form of a matrix using The Zachman framework [18] , [19].

Six different perspectives on the company, representing its main stakeholders: visionaries, chief executives, architects, engineers, executors and workers of the organization are represented in a matrix row [20].

\section{RESULT AND DISCUSSION}

The system design is carried out after collecting data based on a problem-solving approach. The Zachman method is used for design and representation it.

The Zachman Framework is used for designing tourism information system as a promotion containers of tourism business in north sulawesi province.

Table 1: Zachman Framework for Tourism Information System as a promotion containers of tourism business

\begin{tabular}{|c|c|c|c|c|c|c|}
\hline $\begin{array}{l}\text { ABSTRACTION / } \\
\text { PERSECTIVE }\end{array}$ & $\begin{array}{c}\text { DATA / } \\
\text { What }\end{array}$ & $\begin{array}{l}\text { FUNCTION } \\
\text { How }\end{array}$ & $\begin{array}{l}\text { NETWORK } \\
\text { / where }\end{array}$ & $\begin{array}{l}\text { PEOPLE / } \\
\text { Who }\end{array}$ & TIME / When & $\begin{array}{l}\text { MOTIVATION } \\
\text { / Why }\end{array}$ \\
\hline $\begin{array}{l}\text { SCOPE } \\
\text { (CONTEXTUAL) / } \\
\text { Planner }\end{array}$ & $\begin{array}{l}\text { Tourism } \\
\text { Businesses } \\
\text { data }\end{array}$ & $\begin{array}{l}\text { The work } \\
\text { program } \\
\text { reporting } \\
\text { process }\end{array}$ & $\begin{array}{l}\text { Tourism } \\
\text { Businesses } \\
\text { Office }\end{array}$ & $\begin{array}{l}\text { Administrator, } \\
\text { operator } \\
\text { Tourism } \\
\text { Business }\end{array}$ & $\begin{array}{l}\text { Office Data } \\
\text { Input : Work } \\
\text { Program, } \\
\text { socialization }\end{array}$ & $\begin{array}{l}\text { Vision, Mission } \\
\text { tourism } \\
\text { Businesses }\end{array}$ \\
\hline $\begin{array}{l}\text { BUSINESS MODEL } \\
\text { (CONCEPTUAL) / } \\
\text { Owner }\end{array}$ & $\begin{array}{l}\text { Use case } \\
\text { system }\end{array}$ & $\begin{array}{l}\text { activity } \\
\text { diagram }\end{array}$ & $\begin{array}{l}\text { Information } \\
\text { System } \\
\text { Network } \\
\text { Design }\end{array}$ & $\begin{array}{l}\text { Designer, } \\
\text { administrator, } \\
\text { operator }\end{array}$ & $\begin{array}{l}\text { Schedule } \\
\text { information } \\
\text { system project }\end{array}$ & $\begin{array}{l}\text { the reason for } \\
\text { the procurement } \\
\text { of information } \\
\text { systems }\end{array}$ \\
\hline $\begin{array}{l}\text { SYSTEM MODEL } \\
\text { (LOGICAL) / } \\
\text { Designer }\end{array}$ & $\begin{array}{l}\text { ER } \\
\text { Diagram }\end{array}$ & $\begin{array}{l}\text { sequence, } \\
\text { detailed use } \\
\text { case }\end{array}$ & $\begin{array}{l}\text { network } \\
\text { design } \\
\text { proposal }\end{array}$ & $\begin{array}{l}\text { interface } \\
\text { application } \\
\text { design }\end{array}$ & $\begin{array}{l}\text { detail system } \\
\text { schedule }\end{array}$ & $\begin{array}{l}\text { rules in making } \\
\text { models }\end{array}$ \\
\hline $\begin{array}{l}\text { TECHNOLOGY } \\
\text { MODEL } \\
\text { (PHYSICAL) / Builder }\end{array}$ & $\begin{array}{l}\text { Table } \\
\text { Relation }\end{array}$ & $\begin{array}{l}\text { application } \\
\text { usage } \\
\text { process }\end{array}$ & $\begin{array}{l}\text { Location and } \\
\text { technology } \\
\text { used }\end{array}$ & $\begin{array}{l}\text { overview of } \\
\text { the } \\
\text { application } \\
\text { interface }\end{array}$ & $\begin{array}{l}\text { detailed } \\
\text { application } \\
\text { design } \\
\text { schedule }\end{array}$ & $\begin{array}{l}\text { the rules in } \\
\text { making designs }\end{array}$ \\
\hline $\begin{array}{l}\text { DETAIL } \\
\text { REPRESENTATIONS } \\
\text { (OUT-OF-CONTENT) } \\
\text { / sub Contractor }\end{array}$ & $\begin{array}{l}\text { entity } \\
\text { creation } \\
\text { algorithm }\end{array}$ & $\begin{array}{l}\text { report } \\
\text { process } \\
\text { algorithm }\end{array}$ & $\begin{array}{l}\text { Network } \\
\text { configuration }\end{array}$ & $\begin{array}{l}\text { privilege } \\
\text { algorithm }\end{array}$ & $\begin{array}{l}\text { detailed coding } \\
\text { process } \\
\text { schedule }\end{array}$ & $\begin{array}{l}\text { rules in the } \\
\text { coding process }\end{array}$ \\
\hline $\begin{array}{l}\text { FUNCTIONING } \\
\text { ENTERPRISE }\end{array}$ & $\begin{array}{l}\text { an } \\
\text { example } \\
\text { of tourism } \\
\text { Businesses } \\
\text { data } \\
\end{array}$ & $\begin{array}{l}\text { sample } \\
\text { transaction } \\
\text { data in the } \\
\text { system }\end{array}$ & $\begin{array}{l}\text { network } \\
\text { infrastructure }\end{array}$ & $\begin{array}{l}\text { users who use } \\
\text { the system }\end{array}$ & $\begin{array}{l}\text { time schedule } \\
\text { process, } \\
\text { design, } \\
\text { implementation }\end{array}$ & $\begin{array}{l}\text { SOP the system } \\
\text { usage }\end{array}$ \\
\hline
\end{tabular}

\section{CONCLUSION}

Tourism in North Sulawesi Province, which is developing very rapidly, should be able to improve the welfare of the people, including tourism businesses.

Effective promotion of tourism businesses is needed to boost the economic turnover in the tourism sector.

Marketing through the internet network is an effective promotion considering that now is the era of industry 4.0.
The design of a tourism business tourism information system using the Zachman Framework method is a solution to ensure the quality of the software.

This research produces a tourism information system as a promotion containers of tourism business in north sulawesi province design using the zachman framework to ensure quality. 
In the future, the results of this study can be used to build software so that tourism businesses in the northern province can be accessed using the internet network.

\section{ACKNOWLEDGMENTS}

Our On this occasion, the research team would like to thank National Research Agency and Higher Education of the Republic of Indonesia for funding his research through the Directorate of Research and community service in 2020. Also to Manado State Polytechnic and various parties involved in this research.

\section{REFERENCES}

[1] Parassa, Y., Bijang, N. L., \& Pesik, M. U. (2018, October). Online Tourism Architecture Design in North Sulawesi Province. In 2018 International Conference on Applied Science and Technology (iCAST) (pp. 536-539). IEEE

[2] https://beritamanado.com/4-tahun-pertumbuhanpariwisata-600-persen-sulut-dinobatkan-the-risingstar/\#: :text=4\%20Tahun\%20Pertumbuhan\%20Pariwisat a\%20600\%20Persen\%2C\%20Sulut\%20Dinobatkan\%20t he $\% 20$ Rising $\% 20$ Star,by $\% 20 J e r r y \&$ text=Jakarta $\% 20 \% \mathrm{E}$ $2 \% 80 \% 93 \% 20$ Kementerian $\% 20$ Pariwisata $\% 20$ menobatk an $\% 20$ Provinsi,persen $\% 20$ dalam $\% 20$ empat $\% 20$ tahun $\% 2$ Oterakhir, accessed date, August 22, 2020

[3] https://www.kemenparekraf.go.id/post/siaran-persrakornas-pariwisata-iii-bahas-pegembangan-5-destinasisuper-prioritas, accessed date, August 3, 2020 Tavel, P. 2007 Modeling and Simulation Design. AK Peters Ltd.

[4] Joshi, A. A., Dube, S. S., Kadam, O. R., Shilamkar, A. M., \& Bhagat, G. (2016). Tourist Application for Selecting Packages: A Survey. International Journal of Computer Applications, 139(5).

[5] Char-lee, J. M., Becken, S., \& Watt, M. (2016). Learning through a cluster approach: lessons from the implementation of six Australian tourism business sustainability programs. Journal of Cleaner Production, 111, 348-357.

[6] Yonatan Parassa, Mex U Pesik and Nathaniel L Bijang. "Development of Website Model of North Sulawesi Province Tourist Attraction in Multi User". International Journal of Computer Applications 182(11):16-17, August 2018.

[7] Gofman, A., Moskowitz, H. R., \& Mets, T. (2011). Marketing museums and exhibitions: What drives the interest of young people. Journal of Hospitality Marketing \& Management, 20(6), 601-618.
[8] Lu, T. Y., \& Cai, L. A. (2011). An analysis of image and loyalty in convention and exhibition tourism in China. Event Management, 15(1), 37-48.

[9] KAYUMOVICH, Khurramov Ortikjon. Prospects of digital tourism development. Economics, 2020, 1 (44).

[10] Morgan, N. J., Pritchard, A., \& Piggott, R. (2003). Destination branding and the role of the stakeholders: The case of New Zealand. Journal of Vacation Marketing, 9(3), 285-299

[11] Yousaf, S., \& Xiucheng, F. (2018). Halal culinary and tourism marketing strategies on government websites: A preliminary analysis. Tourism Management, 68, 423-443.

[12] Parassa, Y., Pesik, M. U., Pairunan, T. T., \& Pongtuluran, A. K. Enterprise Architecture Planning of North Sulawesi Tourism Information System as a Website Container of the Tourism Office using the Zachman Framework. International Journal of Computer Applications, 975, 8887.

[13] Zarvić, N., \& Wieringa, R. (2014). An integrated enterprise architecture framework for business-IT alignment. Designing Enterprise Architecture Frameworks: Integrating Business Processes with IT Infrastructure, 63(9)r

[14] Forat Falih Hasan. (2018) A Review Study of Information Systems. International Journal of Computer Applications 179(18):15-19

[15] Nogueira, J. M., Romero, D., Espadas, J., \& Molina, A. (2013). Leveraging the Zachman framework implementation using action-research methodologyacase study: aligning the enterprise architecture and the business goals. Enterprise Information Systems, 7(1), 100-132.

[16] [Jamshed, S. (2014). Qualitative research methodinterviewing and observation. Journal of basic and clinical pharmacy, 5(4), 87].

[17] Sowa J, Zachman J. Extending and formalizing the framework for information systems architecture. IBM Systems Journal, 1992: 31, 590-616

[18] Zachman J. A Framework for Information Systems Architecture. IBM Systems Journal, 1987: 26(3), 276 292

[19] Sousa, P., Pereira, C., Vendeirinho, R., Caetano, A., \& Tribolet, J. (2007). Applying the Zachman Framework dimensions to support business process modeling. In Digital Enterprise Technology (pp. 359-366). Springer, Boston, MA. 